\title{
Prevalence of XMRV in blood donors, HTLV and HIV cohorts
}

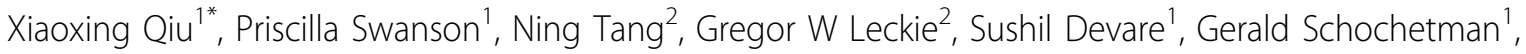 \\ John Hackett Jr ${ }^{1}$ \\ From 15th International Conference on Human Retroviruses: HTLV and Related Viruses \\ Leuven and Gembloux, Belgium. 5-8 June 2011
}

\section{Background}

PCR-based testing has been widely utilized to assess the prevalence of Xenotropic Murine Leukemia Virus-related Virus (XMRV) in prostate cancer and chronic fatigue syndrome patients. An alternative approach, screening for antibodies elicited by XMRV infection, represents a more desirable option for large-scale epidemiologic studies. In this study, blood donor and retrovirus-infected populations were screened for serologic evidence of XMRV infection.

\section{Methods}

Plasma from 1000 US blood donors, 100 HIV-1 infected Cameroonians, 486 HTLV-I infected Japanese, and 156 Japanese HTLV-uninfected controls were screened for antibodies to XMRV gp70 and p15E using recombinantbased chemiluminescence immunoassays (CMIAs). CMIA reactive samples were further evaluated by Western Blot (WB) and real-time RT-PCR for XMRV pol and env sequences.

\section{Results}

Of US donors, $0.8 \%(8 / 1000)$ were CMIA reactive: 1 p15E and 3 of 7 gp70 reactive samples WB confirmed yielding a $0.4 \%$ seroreactive rate. No HIV-1 infected specimens were reactive. Of the Japanese samples, $1 / 156$ uninfected (0.6\%) and 20/486 HTLV-infected samples (4.1\%) had detectable p15E antibodies by CMIA and WB. Eight additional HTLV-infected samples were gp70 reactive; 4 of $486(0.8 \%)$ were gp70 reactive in WB. No XMRV pol or env sequences were detected in the seroreactives.

\footnotetext{
* Correspondence: xiaoxing.qiu@abbott.com

'Abbott Diagnostics, Infectious Diseases, Abbott Park, North Chicago, Illinois, 60064, USA

Full list of author information is available at the end of the article
}

\section{Conclusions}

XMRV seroprevalence ranged from $0-0.6 \%$ in US blood donors, HIV-1 infected and HTLV uninfected subjects. Notably, $4.1 \%$ of Japanese HTLV-I infected individuals were $\mathrm{p} 15 \mathrm{E}$ reactive. Inspection of sequence homology between HTLV and XMRV revealed a high level of conservation within the immunodominant region of HTLV gp21 suggesting increased seroreactivity is due to crossreactive antibodies.

\section{Author details}

'Abbott Diagnostics, Infectious Diseases, Abbott Park, North Chicago, Illinois, 60064, USA. ${ }^{2}$ Abbott Molecular Inc., Des Plaines, IL, 60018, USA.

Published: 6 June 2011

doi:10.1186/1742-4690-8-S1-A222

Cite this article as: Qiu et al:: Prevalence of XMRV in blood donors, HTLV and HIV cohorts. Retrovirology 2011 8(Suppl 1):A222.

\section{() Biomed Central}

(c) 2011 Qiu1 et al; licensee BioMed Central Ltd. This is an open access article distributed under the terms of the Creative Commons Attribution License (http://creativecommons.org/licenses/by/2.0), which permits unrestricted use, distribution, and reproduction in any medium, provided the original work is properly cited.

Submit your next manuscript to BioMed Central and take full advantage of:

- Convenient online submission

- Thorough peer review

- No space constraints or color figure charges

- Immediate publication on acceptance

- Inclusion in PubMed, CAS, Scopus and Google Scholar

- Research which is freely available for redistribution

Submit your manuscript at www.biomedcentral.com/submit

\section{( Biomed Central}

